\title{
The Costs of Immunobiological Losses in Basic Health Units
}

\author{
Daiara Barbosa Torres $^{1}$; \\ Jaqueline Adelaide da Silva \\ Santos $^{2}$; \\ Luana Carvalho Amando \\ Oliveira ${ }^{3}$; \\ Maria Elda Alves de Lacerda \\ Campos \\ Rosana Alves de Melo ${ }^{5}$; \\ Nadja Maria dos Santos ${ }^{6}$; \\ Flávia Emília Cavalcante \\ Valença Fernandes ${ }^{7}$
}

\begin{abstract}
The main objective is to describe the losses of the immunobiologicals per the type and to assess the financial costs of the mentioned losses in the municipality of Petrolina in the year 2013. Method: descriptive and quantitative documentary research. We analyzed the suspected immunobiological reports between January and December 2013. The Mann-Whitney and Kruskal Wallis tests were applied at the significance level of $5 \%$, 95\% confidence interval, using the program Stata 12.0. Approved by the Ethics and Research Committee of the University of Pernambuco CAAE 34873214.1.0000.5207. Results: a loss of 10,439 vaccine doses was observed, with a total financial cost of $\mathrm{R} \$ 72,864.2$. Viral vaccines had the highest losses in the study (55.4\%), with 6,373 doses lost and a total cost of $\mathrm{R} \$ 45,007.7$. Higher financial impacts were caused by influenza followed by pneumococcal 10. Conclusion: losses in the period were significant, both in percentage terms and in monetary values representing costs for health systems.
\end{abstract}

Keywords: Costs; Vaccines; Immunization programs, Unified Health System.

\section{Introduction}

Vaccination has been prominent among public health instruments used by governments and health authorities as it can avoid vaccine-preventable diseases. Being responsible for the reduction in morbidity and mortality, leading to a consequent increase in the expectation and quality of life (Cunha, Krebs, \& Barros, 2009).

\footnotetext{
${ }^{1}$ Nurse by the University of Pernambuco, Petrolina Campus, Pernambuco, Brazil. daiaratorres2008@ hotmail.com;

${ }^{2}$ Graduate Studies in Nursing at the University of Pernambuco (2015).jaqueline_adesantos@ hotmail.com;

${ }^{3}$ Graduate Studies in Nursing at the University of Pernambuco, Petrolina Campus. luanacarvalhoamandoo@ @otmail.com;

${ }^{4}$ Nurse by the Federal University of Pernambuco (1983). Lecturer at the University of Pernambuco and Sanitary nurse - State Health Secretary. Experience in Collective Health, with emphasis on Epidemiology. Master in Health Surveillance by the Faculty of Medical Sciences - UPE (2009). eldalcampos@gmail.com;

${ }^{5}$ Master in Nursing from the State University of Feira de Santana. PhD student by the Postgraduate Program in Therapeutic Innovation (UFPE). Assistant Professor of the University of Pernambuco, Petrolina Campus. Brazil. rosananurse@ hotmail.com;

${ }^{6}$ Master Student by the Postgraduate Program in Sciences: Chemistry of Life- FURG. Assistant Professor of the University of Pernambuco, Petrolina Campus. Brazil.nadja.santos@upe.br

${ }^{7}$ Master in Health Economics and Management by University of Pernambuco. PhD student by the Postgraduate Program in Therapeutic Innovation (UFPE). Assistant Professor of the University of Pernambuco, Petrolina Campus. Brazil. flavia.fernandes@upe.br
} 
However, many countries faces difficulties in acquiring this technology because of their costs or because they don't prioritize policies in this sense (Dias, Almeida, \& Novaes, 2014).

In Brazil, the practice of vaccination began in the twentieth century as a strategy to control contagious diseases such as smallpox epidemics and yellow fever. However, vaccination campaigns reached low coverage and were discontinued (Brazil, 2013b).

Thus, it was necessary to implement the National Immunization Program (PNI) in 1971, promoted by the Ministry of Health, to coordinate actions that had been formerly discontinuous due to their episodic nature and limited coverage, to provide synchronization and rationalization. The PNI's main objective is the eradication and / or control of immunopreventable diseases through basic vaccination strategies (Brazil, 2001).

The PNI serves as a worldwide example, being a reference for immunization actions (Pereira, Neves, Gemelli, \& Ulbricht, 2013). It is guided by nationally established technical standards for the conservation, handling, transport and application of immunobiologicals, as well as scheduling and evaluation aspects (Brazil, 2001). At the same time, it coexists with basic problems such as physical losses of the immunobiologicals due to problems in the "Chain of Cold" (Pereira et al., 2013).

It is necessary to maintain the vaccines in ideal conditions of conservation, using suitable facilities and equipment. Improper handling, faulty equipment, or a lack of electrical power can interrupt the cooling process. When necessary measures are not taken in these intercurrences, there is a impairment in potency and efficacy, leading to immunobiologicals being placed under suspicion or even to their losses (Brazil, 2001).

Within this scenario, nurses constitute the professional technically responsible for the supervision of immunization actions, since they have skills and technical knowledge about immunobiologicals. There are specific ministerial norms and protocols for preparation, administration, transportation, conservation and thermal control, which must be followed in order to avoid unnecessary losses (Brazil, 2014a).

Loss monitoring is important for proper management of the system, since immunobiologicals are high-cost products for public health and may burden the Unified 
Health System (SUS) budget by wasting important resources for the prevention of various immunopreventable diseases (Cunha et al., 2009).

The objective of this study was to describe the losses of immunobiologicals per the type and to assess the financial costs of the said losses in the municipality of Petrolina in the year 2013.

\section{Methods}

A documentary descriptive investigation with a quantitative approach was carried out, including the immunobiological losses in the Health Units of the city of Petrolina, Pernambuco. Located $722 \mathrm{~km}$ from the capital of Pernambuco, Petrolina has a population estimate of 337,683 inhabitants, population density of 64.44 inhabitants per $\mathrm{km}^{2}$ (IBGE, 2016).

The study was composed of a description of the immunobiological losses and the financial costs through suspected immunobiological reports sent by the health units of the municipality to the VIII Regional Health Management (VIII GERES) and evaluated by the technicians of the central level of the State Department of Health of Pernambuco (SES / PE).

We analyzed 48 reports referring to 28 health units, which contained information on losses of immunobiologicals from January to December 2013 and that were analyzed by the coordination of the PNI of SES / PE. All non-correspondent reports were excluded, as well as the ones not in the period established by the survey and the ones not analyzed by the NES coordination of SES / PE.

The data were obtained through the application of a form developed by the researchers, composed of the following variables: health unit address, date of immunobiological notification under suspicion, type of vaccine, total doses lost per vaccine and value of loss by immunobiological.

The survey of the lost doses and their financial costs were collected from the reports of the state PNI in response to the notifications sent by the municipality through the VIII GERES. All necessary data found in these reports were transferred to the collection form, where a number of $388(\mathrm{n}=388)$ occurrences of immunobiological losses were found, meaning the number of times each immunobiological appears in the reports, referring to 17 types of vaccine. 
These vaccines have been classified as viral: all of which are intended to protect against diseases caused by certain types of virus (influenza, human oral rotavirus vaccine (VORH), human antirabies vaccine (VARH), polio vaccine 1, 2 and 3 inactivated (IPV), Polio vaccine 1, 2 and 3 attenuated (OPV), hepatitis B, chickenpox, triple viral, tetra viral and yellow fever). In bacterial: those that are indicated to protect against some types of bacteria (meningococcal C, BCG, double adult (dT), triple bacterial (DTP), pneumococcal 23-valent and 10-valent pneumococcal). And in compounds: those that have mechanisms of defense against both some type of virus and some bacteria (pentavalent).

It should be emphasized that the vaccines were analyzed both individually and according to their characteristics. Costs were also analyzed by individual and aggregate, based on their total, unit and average values. All information was recorded in the Microsoft Excel 2013 program and analyzed by descriptive statistics, measures of central tendency and dispersion. The Mann-Whitney and Kruskal Wallis tests were performed considering the nonnormality of the data by the Shapiro Wilk test $(\mathrm{p}<0.001)$ at a significance level of $5 \%$, a $95 \%$ confidence interval, using the statistical program Stata 12.0 and the results being presented in tables.

The accomplishment of this study took into consideration the ethical aspects of the research involving human beings recommended by the Resolution $\mathrm{N}^{\circ}$. 466, of December 12 , 2012, of the National Health Council (CNS, 2012). The project was approved by the Human Research Ethics Committee of the University of Pernambuco, under CAAE $n^{\circ}$. 34873214.1.0000.5207.

\section{Results}

The main reasons for the losses of the immunobiologicals evaluated in the study were avoidable causes such as lack of energy, inadequate conditioning, equipment failure, accidental disconnection of the socket and disconnection of the circuit breaker.

From the analysis of the reports, it was observed that the months that presented the highest number of occurrences were January 90 (23.2\%), April 79 (20.4\%), February 49 $(12.6 \%)$, and months which had the lowest loss index was July $7(1.8 \%)$ and December 7 $(1.8 \%)$. 
A total of 10,439 missed doses were reported, representing an average loss of 614 doses $(\mathrm{SD}=485)$ per vaccine, ranging from a minimum of one dose lost to a maximum of 1690 per immunobiological dose. The monetary losses reached $\mathrm{R} \$ 72,864.2$, representing an average loss of $\mathrm{R} \$ 4,286.1$ ( $\mathrm{SD}=4.918 .4$ ) per type of vaccine. A significant variation of the sample was observed both in losses and in financial values $(\mathrm{p}<0.05)$.

Viral vaccines had the highest losses in the study, accounting for 215 occurrences (55.4\%), a total of 6,373 doses lost with a total cost of R \$ 45,007.7.

The bacterial vaccines presented 147 (37.9\%) occurrences, with a total of 3,692 doses lost with an average of 25 doses $(\mathrm{SD}=19)$ costing $\mathrm{R} \$ 25,619.8$ (mean value of $\mathrm{R} \$ 174.3$ $(\mathrm{SD}=294.3)$.

The vaccines classified as compounds were the ones that presented the lowest frequency and were responsible for 26 occurrences (6.7\%), with a total of 374 doses lost and with a monetary value of $\mathrm{R} \$ 2,236.8$ representing an average cost of $\mathrm{R} \$ 86.0(\mathrm{SD}=61.3)$ (Table 1).

Table 1 - Distribution of occurrences, missed doses and total value according to immunobiological category. Petrolina, 2013.

\begin{tabular}{|c|c|c|c|c|c|c|c|c|c|c|c|}
\hline \multirow{2}{*}{ Vaccine } & \multicolumn{3}{|c|}{ Occurrences } & \multicolumn{3}{|c|}{ Doses lost } & \multirow{2}{*}{$\begin{array}{c}\text { p- } \\
\text { value }\end{array}$} & \multicolumn{3}{|c|}{$\begin{array}{c}\text { Total value per } \\
\text { immunobiological (R\$) }\end{array}$} & \multirow{2}{*}{$\begin{array}{c}\text { p- } \\
\text { value }\end{array}$} \\
\hline & $\mathbf{n}$ & $\%$ & IC95\% & $\begin{array}{l}\text { Doses } \\
\text { Total }\end{array}$ & $\begin{array}{r}\text { Mea } \\
\mathbf{n}\end{array}$ & SD & & Value & Mean & SD & \\
\hline Viral & 215 & 55,4 & $50,4 \quad 60,4$ & 6.373 & 30 & 43 & \multirow{3}{*}{$\begin{array}{c}0,0245 \\
*\end{array}$} & $45.007,7$ & 209,3 & 352,8 & \multirow{4}{*}{$\begin{array}{c}0,0001 \\
*\end{array}$} \\
\hline Bacterial & 147 & 37,9 & $33,0 \quad 42,7$ & 3.692 & 25 & 19 & & $25.619,8$ & 174,3 & 294,3 & \\
\hline Compound & 26 & 6,7 & $4,2 \quad 9,2$ & 374 & 14 & 10 & & 2236,8 & 86,0 & 61,3 & \\
\hline Total & 388 & 100,0 & & 10.439 & 614 & 486 & & $72.864,2$ & $4.286,1$ & 4918,4 & \\
\hline
\end{tabular}

* Kruskal Wallis test to evaluate the mean difference in the number of doses lost by immunobiological.

There was a significant difference between the occurrences and doses lost according to immunobiological type $(\mathrm{p}<0.05)$. Of the 17 vaccine types that presented loss occurrences, the most frequent were: VARH, hepatitis B and VORH. It was observed that the vaccines that compose the basic vaccination schedule were the ones that presented the greatest number of doses lost, among them influenza with 1,690 doses in 15 occurrences, POV that lost 1,250 doses in 22 occurrences and Hepatitis B with 1,220 doses lost in 41 occurrences (Table 2). 
Table 2 - Descriptive statistics, proportional distribution and financial value of losses per type of immunobiological. Petrolina-PE, 2013

\begin{tabular}{|c|c|c|c|c|c|c|c|c|}
\hline \multirow[b]{2}{*}{ Vaccine } & \multicolumn{4}{|c|}{ Occurrences } & \multicolumn{3}{|c|}{ Doses lost } & \multirow{3}{*}{ p-value } \\
\hline & $\mathbf{n}$ & $\%$ & IC95 & & $\begin{array}{c}\text { Doses } \\
\text { Total }\end{array}$ & Mean & SD & \\
\hline \multicolumn{8}{|l|}{ Viral } & \\
\hline Influenza & 15 & 3,9 & 1,9 & 5,8 & 1690 & 113 & 112 & \multirow{10}{*}{$0,0001 *$} \\
\hline VORH & 39 & 10,1 & 7,0 & 13,1 & 447 & 11 & 7 & \\
\hline VARH & 44 & 11,3 & 8,2 & 14,5 & 365 & 8 & 6 & \\
\hline IPV & 28 & 7,2 & 4,6 & 9,8 & 1250 & 26 & 19 & \\
\hline OPV & 22 & 5,7 & 3,4 & 8,0 & 720 & 57 & 26 & \\
\hline Hepatitis B & 41 & 10,6 & 7,5 & 13,6 & 1220 & 30 & 26 & \\
\hline Chickenpox & 1 & 0,3 & $-0,2$ & 0,8 & 1 & 1 & & \\
\hline Triple Viral & 23 & 5,9 & 3,6 & 8,3 & 660 & 29 & 23 & \\
\hline Tetra Viral & 1 & 0,3 & $-0,2$ & 0,8 & 15 & 15 & & \\
\hline Yellow Fever & 1 & 0,3 & $-0,2$ & 0,8 & 5 & 5 & & \\
\hline
\end{tabular}

Bacterial

\begin{tabular}{lrrrrrrrl}
\hline Meningococcal C & 32 & 8,3 & 5,5 & 11,0 & 551 & 17 & 17 & \\
BCG & 29 & 7,5 & 4,8 & 10,1 & 980 & 34 & 21 & \\
DTP & 26 & 6,7 & 4,2 & 9,2 & 780 & 30 & 17 & \\
dT & 30 & 7,7 & 5,1 & 10,4 & 900 & 30 & 16 & $0,0001^{*}$ \\
Pneumococcal 23 & 8 & 2,1 & 0,6 & 3,5 & 81 & 10 & 16 & \\
Pneumococcal 10 & 22 & 5,7 & 3,4 & 8,0 & 400 & 18 & 13 \\
\hline
\end{tabular}

\section{Compound}

\begin{tabular}{|c|c|c|c|c|c|c|c|c|}
\hline Pentavalent & 26 & 6,7 & 4,2 & 9,2 & 374 & 14 & 10 & \\
\hline Total & 388 & 100,0 & & & 10.439 & 614 & 486 & - \\
\hline
\end{tabular}
immunobiological.

Regarding the financial cost of vaccinations, the ones that caused the greatest impact were influenza with a total cost of $\mathrm{R} \$ 14,588.0$ and an average cost of $\mathrm{R} \$ 970.5(\mathrm{DP}=964.0)$ per occurrence, Pneumococcal disease with a monetary value of $\mathrm{R} \$ 12,566.3$ and an average cost of $\mathrm{R} \$ 571.2(\mathrm{SD}=395.3)$ and meningococcal $\mathrm{C}$ with a cost of $\mathrm{R} \$ 10,135.7$ (average value $\mathrm{R} \$ 316.7, \mathrm{SD}=303.9$ ). The highest value added evidenced by the higher unit price were pneumococcal $10(\mathrm{R} \$ 31.4)$, tetra viral $(\mathrm{R} \$ 28.3)$ and VARH $(\mathrm{R} \$ 26.5)$. 
Regarding the location of the Health unit of the occurrence, the rural zone had the highest number of occurrences. However, the urban area represented the highest cost with losses of $\mathrm{R} \$ 41,938.7$ (Table 3)

Table 3 - Distribution of total and unit values of losses per type of immunobiological. Petrolina-PE, 2013

\begin{tabular}{|c|c|c|c|c|c|}
\hline \multirow{2}{*}{ Vaccine } & \multicolumn{3}{|c|}{$\begin{array}{c}\text { Total value per imunobiological } \\
(\mathbf{R} \$)\end{array}$} & \multirow{2}{*}{$\begin{array}{c}\text { Unitary } \\
\text { Value } \\
\text { (R\$) }\end{array}$} & \multirow{2}{*}{ p-value } \\
\hline & Value & Mean & SD & & \\
\hline \multicolumn{6}{|l|}{ Viral } \\
\hline Influenza & $\begin{array}{l}14.558,0 \\
\end{array}$ & 970,5 & 964,0 & 8,6 & \multirow{10}{*}{$0,0001 *$} \\
\hline VORH & $9.206,4$ & 236,1 & 150,0 & 20,6 & \\
\hline VARH & $9.665,0$ & 219,7 & 159,8 & 26,5 & \\
\hline IPV & $3.799,7$ & 135,7 & 90,0 & 5,3 & \\
\hline OPV & 845,5 & 38,4 & 17,9 & 0,7 & \\
\hline Hepatitis B & $1.729,7$ & 42,2 & 38,1 & 1,4 & \\
\hline Chickenpox & 22,1 & 22,1 & & 22,1 & \\
\hline Triple Viral & $4.752,0$ & 206,6 & 165,9 & 7,2 & \\
\hline Tetra Viral & 424,3 & 424,3 & & 28,3 & \\
\hline Yellow Fever & 5,1 & 5,1 & & 1,0 & \\
\hline \multicolumn{6}{|l|}{ Bacterial } \\
\hline $\begin{array}{l}\text { Meningococcal } \\
\text { C }\end{array}$ & $10.135,7$ & 316,7 & 303,9 & 18,4 & \multirow{6}{*}{$0,0001^{*}$} \\
\hline BCG & $1.078,0$ & 37,2 & 23,9 & 1,1 & \\
\hline DTP & 362,7 & 14,0 & 8,2 & 0,5 & \\
\hline $\mathrm{dT}$ & 342,9 & 11,4 & 6,5 & 0,4 & \\
\hline $\begin{array}{l}\text { Pneumococcal } \\
23\end{array}$ & $1.134,2$ & 141,8 & 223,0 & 14,0 & \\
\hline $\begin{array}{l}\text { Pneumococcal } \\
10\end{array}$ & $12.566,3$ & 571,2 & 395,3 & 31,4 & \\
\hline \multicolumn{6}{|l|}{ Compound } \\
\hline Pentavalent & $2.236,8$ & 86,0 & 61,3 & 6,0 & \multirow[b]{2}{*}{ - } \\
\hline Total & $72.864,2$ & $4.286,1$ & 4918,4 & & \\
\hline \multicolumn{6}{|l|}{ Zone } \\
\hline Urban & $41.938,7$ & 242,4 & 411,4 & & \multirow{2}{*}{$0,0206^{* *}$} \\
\hline Rural & $30.925,5$ & 143,8 & 213,2 & & \\
\hline
\end{tabular}

SD - Standard Deviation * Kruskal Wallis test to evaluate the difference in the mean of the immunobiological values per the characteristic. ** Mann-Whitney test 


\section{Discussion}

The financial costs of the immunobiological losses reported in the present study obtained high financial values reaching $\mathrm{R} \$ 72,864.23$ in one year. Such expense is related to reasons such as lack of power, improper packaging, equipment failure. Attention is drawn to the avoidability of such losses from the follow-up of protocols and care inherent in professional activity.

This value points to the need for changes, since this amount could be invested in new technologies, equipment and training (Pereira et al., 2013). This shows how much these losses can impact at raising public spending, as well as a resource constraint in the health sector. Health organizations need to pursue efficiency, increase productivity, and lower costs. It is necessary to align resources and actions to avoid waste (Castro \& Castilho, 2013).

Studies conducted in other states demonstrate how significant these expenditures are. One of these studies analyzed the losses of rotavirus and triple viral vaccines in vaccination rooms in a city of Minas Gerais. Its result showed a loss of ( $\mathrm{R} \$ 22,206.16)$, and this value was also considered high since the analyzed period was only six months and that only two vaccines included in the NIP were evaluated (Dias et al. Al., 2014).

Another study carried out with the objective of analyzing the distribution of vaccines in the PNI, as well as the dose losses in the Basic Health Units of a municipality in the metropolitan region of Curitiba (PR), showed an annual loss of around R $\$ 1,000,000,00$ (one million reais) with vaccine losses. A total of $\mathrm{R} \$ 3,948,147.00$ in losses in the period studied from 2007 to 2010 (Pereira et al., 2013).

Thus, the relevance of the training contained in the manuals, besides the supervision and monitoring of the process, as well as the maintenance of the refrigeration equipment can be perceived. It is also necessary to have strategic resources to guide measures to prevent and control the risk associated with the occurrence of this type of event (Brazil, 2013a).

Viral vaccines showed a higher occurrence of loss and consequently a large number of missed doses, and may be associated with large temperature fluctuations due to defective equipment, lack of energy, leading to an increase in temperature. Such an event may compromise the immunogenicity of these vaccines. Some of the vaccines classified as viral are more sensitive to high temperatures $\left(>8^{\circ} \mathrm{C}\right)$. Bacterial and composite vaccines, however, 
are more sensitive to low temperatures, with most of them having a higher tolerance at elevated temperatures. However, these temperature changes can also make them unusable (Brazil, 2014b).

It is important to point out that the vaccines of the basic calendar had a higher number of occurrences of losses when compared to the special immunobiological ones. This may be since the number of routine vaccines in the health service is higher than the number of special immunobiologicals that are available to serve the population only when there is a medical request, that is, in emergency situations or when there is an indication especially for its use (Brazil, 2014a).

The immunobiologicals that obtained the highest number of missed doses were influenza, OPV and hepatitis B. The losses related to influenza vaccines and oral polio may possibly be due to the annual vaccination campaigns, where a larger number of doses are available to meet the target public, these losses may have occurred in that period. Another possible cause is requesting doses in excess, but it may also be associated with the lack of vaccine coverage leading to a higher stock of these vaccines.

It is important to consider that the inventory of immunobiologicals in the Health Units should not be greater than the quantities foreseen for consumption, and in campaigns, only the quantities necessary to attend the target public estimated in the period established for the campaign should be maintained (Bahia, 2011).

A study carried out with the objective of increasing the number and identifying the causes of avoidable immunobiological losses in the state of Paraná, in the period from 2009 to 2012, presented similar findings to this study. Vaccines from the basic vaccination schedule were the ones that obtained a greater loss when compared as special immunobiologicals, representing a loss of 3,273,861 (95.2\%) doses. Influenza, OPV and hepatitis B vaccines also showed significant losses and were rendered unusable, leading to financial losses for the municipality (Oliveira, Caveião, \& Crosewski, 2014). Given this, we realize that this is not a unique reality of Petrolina.

Of the vaccines that presented greater financial loss, among them influenza, is justified by the large amount of doses lost, which caused a high cost. The 10-valent pneumococcal which unit value being is the highest among all the vaccines that recorded losses, caused a great impact on the financial value. Meningococcal $\mathrm{C}$ has a significant unit value, which 
associated with the amount of missed doses, generated a higher cost than other immunobiological ones.

It should be noted that immunobiologicals require a high cost for public health and its loss implies not only financial impact, but also represents a shortage of the service directed to attend the population and keep controlled the immunopreventable diseases (Oliveira et al., 2014).

It is important to emphasize that these resources cannot be wasted because they act in the prevention, eradication, elimination and control of immunopreventable diseases, leading to the reduction of morbimortality by certain diseases, and their use is very cost-effective. Viral and bacterial vaccines, either attenuated or inactivated, are effective and stimulate the production of memory cells. These cells will allow the rapid production of specific antibodies at the time of exposure to the causative agent (Brazil, 2014a).

Analyzing the occurrence of events according to the location of the Health Unit, there was a greater frequency of losses in the rural area, which may be related to a precarious infrastructure. Another factor that may occur more frequently in the rural area is lack of energy, as well as the difficulty of access, making it difficult to transfer the immunobiologicals to another location, in the face of some occurrences.

Although the rural area presented a greater number of losses, it was possible to observe that the occurrences of losses with greater financial value were in the urban area. Such concentration in the urban area may be related to a higher stock of vaccines.

The vaccines were discarded from the information passed by the professionals in the reports. Such conduct may have been taken by the difficulty and costs to conduct dose retreats, since vaccines are thermosensitive and probably exposure to temperatures outside the established has generated loss of their immunogenic potential. The cost to PNI for the evaluation of vaccine potency (retests) is high and requires an extended time for verification. Therefore, the National Institute of Quality Control in Health, evaluates the document indicating, when appropriate, the quantitative necessary for the analysis (Brazil, 2013b).

In this context, it is emphasized that the activities of the vaccination room are developed by the nursing team, so it is their responsibility to transmit the information correctly, communicating the various changes (Brazil, 2014a). In this way, the permanent education of the professionals has great potential, and can contribute both to the reduction of 
avoidable losses and mainly to ensure the quality of the immunobiologicals (Soares, Olivo, \& Silva, 2011).

It is important to emphasize that immunobiological costs go beyond those mentioned in this study, if we consider other issues such as the delivery of these resources. A study conducted in India in May and June 2011 to describe the organization, vaccine coverage, and delivery costs of the less expensive oral cholera vaccine using existing public health infrastructure in Odisha, India as a model found that the cost of delivery of the vaccine was \$ 0.49 per dose excluding shipping (Kar et al., 2014).

The World Health Organization (WHO) considers that cost analysis for funding the Comprehensive Multiannual Plan for Immunization is a key factor in the planning process, as it assists in making decisions about program improvements, in addition to generating information that contributes to mobilize the resources needed for vaccines and immunization (WHO, 2006).

Conducting studies on the loss of vaccines helps to define vaccination policies that seek excellence. In addition, it is important to note that these can guide managers and health professionals as to the actions necessary to minimize them, as well as to alert to the waste of public expenditures (Dias et al., 2014).

\section{Conclusion}

The present study identified that the vaccines of the basic vaccination schedule, such as OPV and influenza and hepatitis B, showed the highest losses of doses and that the occurrences with greater financial value besides the losses of the viral vaccines. These results are worrying, since these losses of immunobiological were due to preventable causes, which reflects the disruption of the health service in which the nurse is responsible for the management.

Thus, it is suggested the need for the nursing professional to reflect on the organization of the services regarding requests for immunobiologicals proportional to the demand, as well as the training of these professionals to assure the quality of the vaccines and the immunization of the population with the certainty of the immunobiological efficacy. In addition to the possible replacement of refrigeration equipment. 


\section{References}

Bahia. (2011). Manual de Procedimentos para Vacinação. Série A. Normas e Manuais Técnicos. Bahia: Secretaria da Saúde do Estado da Bahia.

Brasil. (2001). Manual de Rede de Frio. Brasília: Ministério da Saúde.

Brasil. (2013a). Manual de rede de frio do Programa Nacional de Imunizações. (M. da Saúde, Ed.) (4th ed.). Brasília: Ministério da Saúde.

Brasil. (2013b). Programa Nacional de Imunizações: 40 anos. Manual Técnico, Brasília: Ministério da Saúde. Retrieved from http://bvsms.saude.gov.br/bvs/publicacoes/programa_nacional_imunizacoes_pni40.pdf

Brasil. (2014a). Manual de Normas e Procedimentos para Vacinação. (M. da Saúde, Ed.). Brasília: Ministério da Saúde. Retrieved from http://bvsms.saude.gov.br/bvs/publicacoes/manual_procedimentos_vacinacao.pdf.

Brasil. (2014b). Manual dos Centros de Referência para Imunobiológicos Especiais. Manual Técnico, Brasília: Ministério da Saúde. Retrieved from http://portalsaude.saude.gov.br/images/pdf/2014/dezembro/09/manual-cries-9dez14-web.pdf

Castro, L. C. De, \& Castilho, V. (2013). O custo de desperdício de materiais de consumo em um centro cirúrgico. Revista Latino-Americana de Enfermagem, 21(6), 1228-34. http://doi.org/10.1590/0104-1169.2920.2358

CNS, C. N. de hoje. (2012). Resolução 466 do Comité de Ética.

Cunha, J., Krebs, L., \& Barros, E. (2009). Vacinas e imunoglobulinas: consulta rápida. Porto Alegre: Artmed.

Dias, B. F., Almeida, R., \& Novaes, M. (2014). Perdas das Vacinas Rotavírus e Tríplice Viral em Salas de Vacinação de um Município Mineiro. XXIV Congresso Brasileiro de Engenharia Biomédica. Rio de Janeiro: CBEB. Retrieved from http://www.canal6.com.br/cbeb/2014/artigos/cbeb2014_submission_094.pdf

IBGE. (2016). Instituto Brasileiro de Geografia e Estatística. Instituto Brasileiro de Geografia e Estatística. Retrieved from http://cidades.ibge.gov.br/xtras/perfil.php?lang=\&codmun=261110\&search=pernambuco|petr olina|infograficos:-informacoes-completas

Kar, S. K., Sah, B., Patnaik, B., Kim, Y. H., Kerketta, A. S., Shin, S., ... Wierzba, T. F. (2014). Mass Vaccination with a New, Less Expensive Oral Cholera Vaccine Using Public 
Health Infrastructure in India: The Odisha Model. PLoS Neglected Tropical Diseases, 8(2). http://doi.org/10.1371/journal.pntd.0002629

Oliveira, V. C., Caveião, C., \& Crosewski, F. (2014). Gerenciamento de enfermagem no controle de perdas evitáveis de imunobiológicos. Cogitare Enfermagem, 19(4), 679-686. Retrieved from http://ojs.c3sl.ufpr.br/ojs/index.php/cogitare/article/view/36358/23921

Pereira, D., Neves, E., Gemelli, M., \& Ulbricht, L. (2013). Análise da taxa de utilização e perda de vacinas no programa nacional de imunização. Cad. Saúde Colet., 21(4), 420-424. http://doi.org/10.1590/S1414-462X2013000400010

Soares, K. R. A., Olivo, L. C. C. de, \& Silva, M. L. B. da. (2011). Ações para Eliminar as Perdas Físicas de Vacinas no Município de Florianópolis. Coleção Gestão Da Saúde Pública. Retrieved from http://gsp.cursoscad.ufsc.br/wp/wp-content/uploads/2013/03/Artigo-05.pdf

WHO. (2006). Immunization Costing e Financing: A Tool and User Guide for comprehensive Multi-Year Planning (cMYP). Switzerland: World Health Organization. Retrieved from http://apps.who.int/iris/bitstream/10665/128051/1/WHO_IVB_14.06_eng.pdf?ua=1

\section{How to cite this article (APA):}

Torres, D.B.; Santos, J.A.S.S.; Oliveira, L.C.A. Campos, M.E.A.L.; Melo, R.A.; Santos, N.M.; Fernandes, F.E.C.V. (2016). The costs of immunobiological losses in Basic Health Units. Am. In. Mult. J., Fev. 1 (2), 4-16.

Received: $2016 / 5 / 12$

Accepted: 2016/5/23 